\title{
HUBUNGAN ANTARA TEKANAN DARAH SISTOLIK DENGAN KADAR HDL KOLESTEROL PADA PASIEN DIABETES MELITUS TIPE 2 DI KLINIK ARAFAH LAMPUNG TENGAH
}

\author{
Toni Prasetia ${ }^{1}$, Firhat Esfandiari ${ }^{2}$, Sandhy Arya Pratama ${ }^{3}$, Ikbal Zaenur \\ Ridwan $^{4^{*}}$
}

\begin{abstract}
1Departemen Penyakit Dalam Fakultas Kedokteran Universitas Malahayati ${ }^{2}$ Departemen Histologi Fakultas Kedokteran Universitas Malahayati

${ }^{3}$ Staf Pengajar Fakultas Kedokteran Universitas Malahayati

${ }^{4}$ Program Studi Kedokteran Universitas Malahayati
\end{abstract}

Email Korespondensi: zaenurridwanikbal@gmail.com

\section{ABSTRACT: RELATIONSHIP BETWEEN SYSTOLIC BLOOD PRESSURE AND HDL CHOLESTEROL LEVELS IN TYPE 2 DIABETES MELLITUS PATIENTS IN ARAFAH CLINIC, CENTRAL LAMPUNG}

Background: Hypertension is a major risk factor for type 2 Diabetes Mellitus, hypertension can make cells insensitive to insulin, so blood sugar levels can also be disrupted. Dyslipidimia causes constriction in blood vessels or atherosclerosis which can aggravate hypertension or diabetes mellitus. Meanwhile, the function of HDL in transporting bad cholesterol also causes blood vessels to dilate due to increased NO production.

Objective: To find out the relationship between systolic blood pressure and HDL cholesterol levels in type 2 diabetes mellitus patients at the Arafah Clinic, Central Lampung, 2020.

Method: This type of research used in this research is descriptive analytic with cross sectional design. The sampling technique was total sampling. Respondents in this study were patients with Type 2 Diabetes Mellitus at the Arafah Clinic in Central Lampung in 2020

Results: Based on the results of the chi-square statistical test, it was found that there was no relationship with the results of $p=0.898(p>0.05)$.

Conclusion: There is no correlation between systolic blood pressure and HDL cholesterol levels in type 2 diabetes mellitus patients at the Arafah Clinic, Central Lampung in 2020.

Keywords: Diabetes Mellitus type 2, Systolic Blood Pressure, HDL

INTISARI: HUBUNGAN TEKANAN DARAH SISTOLIK DENGAN KADAR KOLESTEROL HDL PADA PASIEN DIABETES MELLITUS TIPE 2 DI KLINIK ARAFAH LAMPUNG TENGAH

Latar Belakang: Hipertensi merupakan faktor risiko utama untuk terjadinya Diabetes Melitus tipe 2, hipertensi dapat membuat sel tidak sensitif terhadap insulin, maka kadar gula di dalam darah juga dapat mengalami gangguan. Dislipidimia menyebabkan terjadinya penyempitan dalam pembuluh darah atau aterosklerosis yang dapat memperberat kondisi hipertensi ataupun diabetes 
mellitus. Sedangkan fungsi HDL mengangkut kolesterol jahat juga menyebabkan pembuluh darah bisa berdilatasi karena produksi NO yang meningkat.

Tujuan: Untuk mengetahui Hubungan Antara Tekanan Darah Sistolik dengan Kadar HDL Kolesterol pada pasien Diabetes Melitus tipe 2 di Klinik Arafah Lampung Tengah Tahun 2020.

Metode: Jenis penelitian yang digunakan dalam penelitian ini adalah deskriptif analitik dengan desain cross sectional. Teknik pengambilan sampel berupa total sampling. Responden dalam penelitian ini adalah pasien Diabetes Melitus tipe 2 di Klinik Arafah Lampung Tengah.

Hasil: Berdasarkan hasil uji statistic chi-square didapatkan tidak terdapat hubungan dengan hasil $p=0,898(p>0,05)$.

Kesimpulan: Tidak terdapat Hubungan Antara Tekanan Darah Sistolik dengan Kadar HDL Kolesterol pada pasien Diabetes Melitus tipe 2 di Klinik Arafah Lampung Tengah tahun 2020.

Kata Kunci : Diabetes Melitus tipe 2, Tekanan Darah Sistolik, HDL

\section{PENDAHULUAN}

Diabetes Melitus (DM) merupakan kumpulan gejala yang timbul pada seseorang disebabkan karena adanya peningkatan kadar glukosa darah akibat penurunan sekresi insulin yang progresif dilatarbelakangi oleh resistensi insulin (Fidayana et al,.2020). Diabetes diklasifikasikan menjadi, antara lain DM tipe 1, DM tipe 2, DM gestasional, dan DM spesifik lainnya (Suwinawati et al,. 2020). Diabetes Melitus tipe 2 disebabkan faktor risiko tidak dapat berubah seperti jenis kelamin, umur, genetik dan faktor risiko yang dapat berubah seperti kebiasaan merokok, tingkat pendidikan, aktivitas fisik, pekerjaan, konsumsi alcohol, IMT, dan lingkar pinggang (Fidayana et al,. 2020). Diabetes Melitus yang tidak dikelola dengan baik dapat mengakibatkan komplikasi vaskuler, salah satunya hipertensi (Sari et al,. 2017).

Secara global, diperkirakan 422 juta orang dewasa hidup dengan diabetes pada tahun 2014, dibandingkan dengan 108 juta pada tahun 1980. Prevalensi diabetes di dunia (dengan usia yang distandarisasi) telah meningkat hampir dua kali lipat sejak tahun
1980, meningkat dari 4,7\% menjadi $8,5 \%$ pada populasi orang dewasa. Selama beberapa decade terakhir, prevalensi diabetes meningkat lebih cepat dibandingkan di Negara dengan penghasilan rendah dan menengah daripada di Negara dengan penghasilan tinggi (KEMENKES RI, 2019).

World Health Organization (WHO) memprediksi kenaikan jumlah penderita diabetes melitus tipe $2 \mathrm{di}$ Indonesia dari 8,4 juta tahun 2000 menjadi sekitar 21,3 juta pada tahun 2030. Sedangkan Prediksi Internasional Diabetes Federation (IDF) juga menjelaskan pada tahun 2013-2017 terdapat kenaikan penderita Diabetes Melitus dari 10,3 juta menjadi 16,7 juta pada tahun 2045. (PERKENI, 2019).

Menurut Dinas Kesehatan Provinsi Lampung (2015), penderita DM pada tahun 2014 di Provinsi Lampung yaitu sebanyak 69.282 dengan prevalensi sebesar 0,9\% (Zahra, 2018). Serta angka kejadian DM di Kabupaten Lampung Tengah mengalami peningkatan sebesar 9\% yaitu sebnayak 581 kasus (Zulfian et al., 2020).

Hipertensi adalah penyakit tidak menular (PTM) yang merupakan salah satu penyebab utama kematian 
premature di dunia (KEMENKES RI, 2019). Hipertensi merupakan faktor risiko utama untuk terjadinya Diabetes Melitus. Hubungannya dengan DM tipe 2 sangatlah kompleks, hipertensi dapat membuat sel tidak sensitif terhadap insulin (resisten insulin), Insulin berperan untuk membawa glukosa ke sel dan dengan cara ini juga mengatur metabolisme karbohidrat, sehingga jika terjadi resistensi insulin oleh sel, maka kadar gula di dalam darah juga dapat mengalami gangguan (Mutamaina, 2013).

World Health Organization (WHO) memperkirakan saat ini prevalensi hipertensi di dunia sebesar 22\% dari keseluruhan penduduk dunia. Dari sejumlah penderita tersebut, hanya kurang dari satu perlima melakukan upaya pengendlian terhadap tekanan darah yang dimiliki penderita. Wilayah afrika memiliki prevalensi hipertensi tertinggi sebesar $27 \%$. Asia Tenggara menempati posisi ke3 setelah Mediterania Timur dengan prevalensi sebesar 25\% terhadap penduduk total. WHO juga memperkirakan 1 diantara 5 perempuan diseluruh dunia memiliki hipertensi sedangkan laki-laki 1 diantara 4. Menurut Laporan RISKESDAS tahun 2018 prevalensi hipertensi di Indonesia penduduk umur $>18$ tahun mengalami peningkatan dari sebelumnya $25.8 \%$ pada tahun 2013 menjadi 34.1\% pada tahun 2018. Prevalensi di Provinsi Lampung tersendiri yaitu $29.9 \%$ (KEMENKES RI, 2019).

Berdasarkan data BPJS Regio Metro, didapatkan bahwa Kabupaten Lampung Tengah menduduki peringkat tertinggi angka kejadian DM dan Hipertensi, dengan jumlah 11.614 pasien DM dan 54.118 pasien Hipertensi. Klinik Arafah merupakan salah satu Fasilitas Kesehatan Tingkat Pertama di Lampung Tengah yang memiliki jumlah pasien DM dan Hipertensi terbanyak yaitu 820 pasien DM dan 3.726 pasien Hipertensi (BPJS Regio Metro,2020).

Gangguan profil lipid berhubungan dengan diabetes melitus dan penyakit jantung. Dislipidimia menyebabkan terjadinya penyempitan dalam pembuluh darah yang dapat memperberat kondisi hipertensi ataupun diabetes mellitus (Noviyanti, Decroli dan Sastri, 2015). Profil Lipid abnormal yang utama seperti kenaikan kadar kolesterol total, TG, LDL, serta penurunan HDL(Nuriska dan Saraswati, 2011). Profil lipid yang abnormal ini menyebabkan kolesterol mudah menempel pada dinding pembuluh darah coroner sehingga menimbulkan aterosklerosis (timbunan lemak pada dinding pembuluh darah) kerusakan pada endotel yang memberi dampak hilangnya aktifitas vasomotor dan bisa bermanifestasi pada kenaikan TD (Setiati et al., 2014). Dislipidemia adalah salah satu faktor yang memegang peranan dalam patogenesis dan perkembangan komplikasi DM berupa makrovaskular maupun mikrovaskular (Yurianto, et al., 2017). HDL (High Density Lipoprotein) adalah salah satu dari profil lipid yang bersifat baik bagi pasien, berfungsi mengambil kolesterol jahat yang berada didalam pembuluh darah sehinga tidak terjadi akumulasi kolesterol dalam endotel selanjutnya diangkut ke hati dan dibuang melalui saluran pencernaan. Aterosklerosis adalah kondisi terjadinya akumulasi kolesterol jahat pada endotel pembuluh darah. Fungsi dari HDL selain mengangkut kolesterol jahat juga menyebabkan pembuluh darah bisa berdilatasi karena produksi NO yang meningkat (Rafsanjani et al., 2019).

Berdasarkan uraian diatas, melihat banyaknya kasus Hipertensi dan Diabetes Melitus di Indonesia, 
didukung dengan gangguan profil lipid yang merupakan faktor terjadinya Hipertensi pada pasien DM. Maka peneliti ingin meneliti hubungan Hipertensi dengan kadar HDL kolesterol pada pasien DM tipe 2 di Klinik Arafah Lampung Tengah.

\section{METODE}

Penelitian ini menggunakan metode penelitian deskriptif analitik dengan pendekatan cross sectional. Penelitian ini dilakukan di Klinik Arafah Lampung Tengah Provinsi Lampung Pada Bulan Desember 2020 s.d selesai. Populasi penelitian ini adalah seluruh pasien DM tipe 2 di Klinik Arafah tahun 2020. Sampel diambil dari pasien DM tipe 2 yang memiliki rekam medik kadar HDL Kolesterol di Klinik Arafah Lampung Tengah. Teknik Pengambilan Sampel yang digunakan total sampling.

HASIL

Didapatkan dari data rekam medik yang terdiagnosa Diabetes Melitus tipe 2 dengan jumlah 46 pasien. Terdiri dari 16 Laki-Laki dan 30 Perempuan.

Tabel 1 Analisis Data Univariat

\begin{tabular}{|c|c|c|}
\hline Variabel & Frekuensi & Persentase \\
\hline \multicolumn{3}{|c|}{ Jenis Kelamin } \\
\hline Laki-laki & 16 & $34,8 \%$ \\
\hline Perempuan & 30 & $62,5 \%$ \\
\hline Total & 46 & $100 \%$ \\
\hline \multicolumn{3}{|l|}{ Usia } \\
\hline $24-45$ & 7 & $15,2 \%$ \\
\hline $46-65$ & 28 & $69,6 \%$ \\
\hline$>65$ & 4 & $15,2 \%$ \\
\hline Total & 46 & $100 \%$ \\
\hline \multicolumn{3}{|c|}{ Tekanan Darah Sistolik } \\
\hline$<140$ & 34 & $73,9 \%$ \\
\hline$\geq 140$ & 12 & $26,1 \%$ \\
\hline Total & 46 & $100 \%$ \\
\hline \multicolumn{3}{|c|}{ High Density Lipoprotein } \\
\hline$\leq 60$ & 37 & $80,4 \%$ \\
\hline$>60$ & 9 & $19,6 \%$ \\
\hline Total & 46 & $100 \%$ \\
\hline
\end{tabular}

Berdasarkan Tabel 1 Diketahui bahwa Distribusi Frekuensi pendereita DM tipe 2 berdasarkan Jenis Kelamin adalah 16 Laki-laki (34.8\%) dan 30 Perempuan (65.2\%), lalu berdasarkan usia adalah $24-24$ tahun dengan jumlah 7 (15.2\%), 4665 tahun jumlah 32 (69.6\%) dan diatas 65 tahun jumlah 7 (15.2\%), Selanjutnya berdasarkan TDS yaitu kurang dari $140 \mathrm{mmHg}$ dengan jumlah 34 (73.9\%) dan lebih dari sama dengan $140 \mathrm{mmHg}$ dengan jumlah $12 \quad(26.1 \%) \quad$ dab=n yang terakhu berdasarkan kadar HDL adalah kurang dari sama dengan 60 $\mathrm{mg} / \mathrm{dl}$ dengan jumlah 37 yaitu (80.4\%) dan lebih dari $60 \mathrm{mg} / \mathrm{dl}$ dengan jumlah 9 (19.6\%). 
Tabel 2 Analisis Data Bivariat

\begin{tabular}{cccccccc}
\hline \multirow{2}{*}{$\begin{array}{c}\text { Tekanan Darah } \\
\text { Sistolik }\end{array}$} & \multicolumn{4}{c}{$\begin{array}{c}\text { High Density } \\
\text { Lipoprotein }\end{array}$} & \multirow{2}{*}{ Jumlah } & \multirow{2}{*}{ Nilai p } \\
\cline { 2 - 6 } & \multicolumn{3}{c}{$\leq 60$} & \multicolumn{2}{c}{$>60$} & & \\
\cline { 2 - 7 } & $\mathrm{n}$ & $\%$ & $\mathrm{~N}$ & $\%$ & $\mathrm{n}$ & $\%$ & \multirow{2}{*}{0.898} \\
\hline$<140$ & 28 & 82,4 & 6 & 17,6 & 34 & 100 & \\
$>140$ & 9 & 75 & 3 & 25 & 12 & 100 & \\
\hline Jumlah & 37 & 80,4 & 9 & 19,6 & 46 & 100 & \\
\hline
\end{tabular}

Hasil analisis data Tabel 2 menggunakan rumus chi-square dengan uji alternatif fisher exact dengan tingkat kesalahan (alpha) 0,05 didapatkan $\mathrm{P}$ value = $0,898(P>0,05)$, maka dapat

\section{PEMBAHASAN}

\section{Jenis Kelamin}

Didapatkan hasil bahwa Distribusi Frekuensi Jenis Kelamin adalah 16 Laki-laki (34.8\%) dan 30 Perempuan (65.2\%). Menujukan bahwa Perempuan lebih banyak dari lakilaki yang menderita Diabetes Melitus, hal ini sesuai dengan Prevalensi DM pada tahun 2018 berdasarkan diagnosis Dokter bahwa penderita DM di Indonesia bahwa jenis kelamin Perempuan lebih banyak $0,6 \%$ dibandingkan laki-laki, yakni perempuan $1,8 \%$ dan laki-laki 1,2\% (KEMENKES RI, 2019).

Penelitian sebelumnya yang dilakukan oleh Okta Mustipah pada tahun 2019 di Yogyakarta menyatakan bahwa dari 80 responden, jenis kelamin perempuan paling banyak yaitu sebanyak 53 orang $(66,2 \%)$ sisanya laki-laki yang berjumlah 27 orang $(33,8 \%)$ (Mustipah, 2019). Hasil penelitian lain juga menunjukan bahwa persentasi pasien diabetes pada perempuan lebih besar dibanding laki-laki. Perempuan memiliki komposisi lemak lebih tinggi dibanding laki-laki, sehingga perempuan lebih mudah gemuk yang berkitan dengan risiko obesitas dan diabetes (Komariah, 2020). disimpulkan bahwa tidak ada hubungan yang signifikan antara tekanan darah sistolik dengan kadar HDL kolesterol pada pasien DM tipe 2.

\section{Umur}

Didapatkan hasil bahwa Distribusi Frekuensi Umur adalah 24-24 tahun dengan jumlah 7 yaitu (15.2\%), 46-65 tahun jumlah 32 yaitu (69.6\%) dan diatas 65 tahun jumlah 7 yaitu (15.2\%). Hasil penelitian ini sama dengan hasil penelitian Komariah dan Sri Rahayu (2020) yang menunjukkan bahwa penderita diabetes melitus tipe 2 paling banyak dialami pada pasien usia 4665 (69,4\%). Begitu pula pada penelitian di Klinik Dokter Praktik Mandiri Hakikiyah Lampung Tengah tahun 2019 menunjukan bahwa prevalensi DM yang berusia <45 tahun hanya 7 orang $(12,5 \%)$ dan usia $\geq 45$ tahun sebanyak 49 orang (87,5\%) (Zulfian et al., 2020).

Hal ini menunjukkan bahwa diabetes sering kali muncul setelah seseorang memasuki usia rawan, terutama setelah usia 45 tahun. Seseorang dengan usia lebih dari 45 tahun memiliki peningkatan risiko terhadap terjadinya DM dan intoleransi glukosa yang disebabkan oleh faktor degeneratif yaitu menurunnya fungsi tubuh, khususnya kemampuan dari sel beta dalam memprouksi insulin, sehingga kadar 
glukosa darah meningkat (Purwanti et al., 2016).

\section{Tekanan Darah Sistolik}

Didapatkan hasil bahwa Distribusi Frekuensi Tekanan Darah Sistolik adalah kurang dari $140 \mathrm{mmHg}$ atau normal dengan jumlah 34 yaitu (73.9\%) dan lebih dari sama dengan $140 \mathrm{mmHg}$ dengan jumlah 12 yaitu (26.1\%). Sama halnya dengan penelitian yang dilakukan oleh Winta dkk (2018), dengan hasil tekanan darah pada lansia penderita DM 2 di Poli Penyakit Dalam RSD Mardi Waluyo Blitar menunjukan bahwa sebagian besar responden memiliki tekanan darah normal sebanyak 42 orang atau $56 \%$ dari total 75 orang. Tekanan darah merujuk kepada tekanan yang dialami darah pada pembuluh arteri ketika darah di pompa oleh jantung ke seluruh anggota tubuh manusia. Diketahui bahwa tekanan darah dapat disebabkan oleh beberapa faktor, antara lain usia, jenis kelamin, penyakit penyerta, faktor keturunan, faktor demografi (Winta et al., 2018).

\section{HDL Kolesterol}

Didapatkan hasil bahwa Distribusi Frekuensi Kadar HDL Kolesterol adalah kurang dari sama dengan 60 $\mathrm{mg} / \mathrm{dl}$ dengan jumlah 37 yaitu (80.4\%) dan lebih dari $60 \mathrm{mg} / \mathrm{dl}$ dengan jumlah 9 (19.6\%). Sejalan dengan penelitian Purwanti dkk (2016) hasil penelitian kolesterol HDL pada pasien DM tipe 2 di Poliklinik Diabetic Centre RSUP Sanglah bahwa Sebagian besar responden menunjukan kadar HDL kolesterol yang tidak normal atau rendah yaitu sebanyak 27 responden dari total keseluruhan 35 responden. HDL kolesterol merupakan jenis pengangkut kolesterol yang baik karena mampu menyapu kolesterol yang berada di dinding pembuluh darah, HDL mengangkut kolesterol dan dibawa ke hati untuk diolah dan diubah menjadi garam empedu.

\section{Hubungan antara Tekanan Darah Sistolik dengan Kadar HDL Kolesterol}

Untuk mengetahui hubungan antara variabel bebas dan variabel tergantung dilakukan uji Chisquare atau Fisher exact melalui crosstabulasi. Hasil crosstabulasi antara kadar HDL kolesterol dengan tekanan darah sistolik dapat dilihat pada tabel 2 hasil crosstabulasi memiliki tingkat kebermaknaan yang tidak signifikan yakni $0,898 \quad(p \geq$ 0,05).

Dan dari hasil uji hipotesis komparatif pada Fisher Exact menyatakan tidak terdapat hubungan kadar HDL kolesterol dengan tekanan darah sistolik. Hal ini ditunjukan dari nilai Significancy $\geq 0,05$. Berdasarkan hasil yang diperoleh dari uji deskriptif, pada pasien DM tipe 2 dengan kadar HDL kolesterol yang rendah mendominasi adalah pasien dengan tekanan darah sistolik normal. Hal ini berbanding lurus dengan hasil uji hipotesis komparatif pada Fisher exact yang mengemukakan tidak adanya hubungan antara kadar HDL kolesterol dengan hipertensi sistolik.

Hasil penelitian ini berbeda dengan Penelitian yang berjudul "Hubungan Kadar High Density lipoprotein (HDL) dengan Kejadian Hipertensi" yang dilakukan Rafsanjani dkk (2019) menunjukan hasil bahwa terdapat hubungan antara kadar HDL rendah atau berisiko terhadap kejadian Hipertensi. 


\section{KESIMPULAN}

Berdasarkan analisa dan pembahasan diatas, tidak terdapat hubungan anara tekanan darah sistolik dengan kadar HDL Kolesterol pada pasien Diabetes Melitus tipe 2 di Klinik Arafah Lampung Tengah.

\section{SARAN}

Masyarakat agar lebih memperhatikan kesehatan salah satunya dengan pembatasan asupan makanan untuk menurunkan kadar lipid sebagai preventif yang berpotensi penyakit diabetes. Dan melakukan gerakan hidup sehat dengan melakukan senam satu kali dalam seminggu atau bisa dengan olahraga jenis lainnya. Perlu dilakukan penelitian yang lebih luas cakupan faktor yang mempengaruhi kadar kolesterol pada pasien DM sehingga dapat menjadi suatu pertimbangan atau perbandingan untuk perencanaan program .

\section{DAFTAR PUSTAKA}

Fidyana, M., Esfandiari, F., Maharyuni, E. \& Nur, M., (2020). Hubungan Indeks Massa Tubuh dengan kaddar HDL pada pasien Diabetes Melitus tipe 2. Jurnal IImiah Kesehatan Sandi Husada, 11(1), pp. 392-396.

KEMENKES RI, (2019). Hari Diabetes Sedunia. InfoDATIN, pp. 1-10.

KEMENKES RI, (2019). Hipertensi Si Pembunuh Senyap. InfoDATIN, pp. 1-10.

Komariah \& Rahayu, S. (2020). Hubungan Usia, Jenis Kelamin dan Indeks Massa Tubuh dengan Kadar Gula Darah Puasa pada Pasien Diabetes Melitus tipe 2 di Klinik Pratama Rawat Jalan Proklamasi, Depok, Jawa Barat. Jurnal Kesehatan Kusuma Husada, pp. 41-50.
Mutamainah, I. (2013). Hubungan Kadar Gula Darah dengan Hipertensi pada Pasien Diabetes Melitus Tipe 2 di Rumah Sakit Umum daerah Karanganyar.

Noviyanti, F., Decroli, E. \& Sastri, S. (2015). Perbedaan Kadar LDL-Kolesterol pada Pasien Diabetes Melitus Tipe 2 dengan dan tanpa Hipertensi di RS Dr. M. Djamil Padang Tahun 2011. Jurnal Kesehatan Andalas, 4(2), pp. 545-550.

Nuriska, A. S. I. \& Saraswati, M. R. (2011). Hubungan Kadar Kolesterol Total dengan Hipertensi Sistolik pada pasien Diabetes Melitus tipe 2 di Poliklinik Endokrin Rumah Sakit Umum Sanglah Periode Januari-Desember 2011. pp. 1-7.

PERKENI. (2019). Pedoman Pengelolaan Dan Penvegahan Diabetes Melitus tipe 2 Dewasa di Indonesia. s.l.:PB PERKENI

Purwanti, N. W. N. A., Jirna, I. N. \& Arjani, I. A. M. S. (2016). Analisis Hubungan Kadar Gula Darah Puasa dengan Kadar Kolesterol High Density Lipoprotein (HDL) pada Pasien Diabetes Melitus tipe 2 di RSUP Sanglah. Meditory, 4(2), pp. 65-71.

Rafsanjani, M. S., Asriati, Kholidha, A. N. \& Alifariki, L. O. (2019). Hubungan kadar High Density Lipoprotein (HDL) dengan Kejadian Hipertensi. Jurnal Kedokteran dan Kesehatan, 13(2), pp. 74-81.

Sari, G. P. et al., (2017). Faktor Risiko yang Berpengaruh terhadap Terjadinya Hipertensi pada Penderita Diabetes Melitus Tipe II di Wilayah Puskesmas Kabupaten Pati. Jurnal 
Epidemiologi Kesehatan Komunitas, 2(2), pp. 54-61.

Setiati, S. et al., (2014). Buku Ajar Ilmu Penyakit Dalam Jilid I. Jakarta: InternaPublishing.

Suwinawati, E., Ardiani, H. \& Ratnawati, R., (2020). Hubungan Obesitas dengan Kejadian Diabetes Melitus tipe 2 di Pos Pembinaan Terpadu Penyakit Tidak Menular Puskesmas Kendal Kabupaten Ngawi. Journal of Health Science and Prvention, 4(2), pp. 79-83.

Winta, A. E., Setiyorini, E. \& Wulandari, N. A., ()2018. Hubungan Kadar Gula Darah dengan Tekanan Darah pada Lansia Penderita Diabetes tipe 2. Jurnal Ners dan
Kebidanan, 5(2), pp. 163171.

Yurianto, N. P., Santosa, A. \& Al Munawir, (2017). Hubungan antara Kadar LDL dan HDL terhadap kejadian Kaki Diabetik paada Pasien DM Tipe 2 di Poli Interna RSD dr. Soebandi: Penelitian Case Control. e-Jurnal Pustaka Kesehatan, Mei, 5(2), pp. 544-548.

Zulfian, Esfandiari, F., Anggraeni, S. \& Selviani, A., (2020). Hubungan Antara Indeks Massa Tubuh dengan Kadar Trigliserida pada Pasien FKTP Diabetes Melitus Tipe II di Dokter Praktik Mandiri KHakikiyah Lampung Tengah Agustus 2019. Jurnal Medika Malahayati, 4(1), pp. 39-46. 